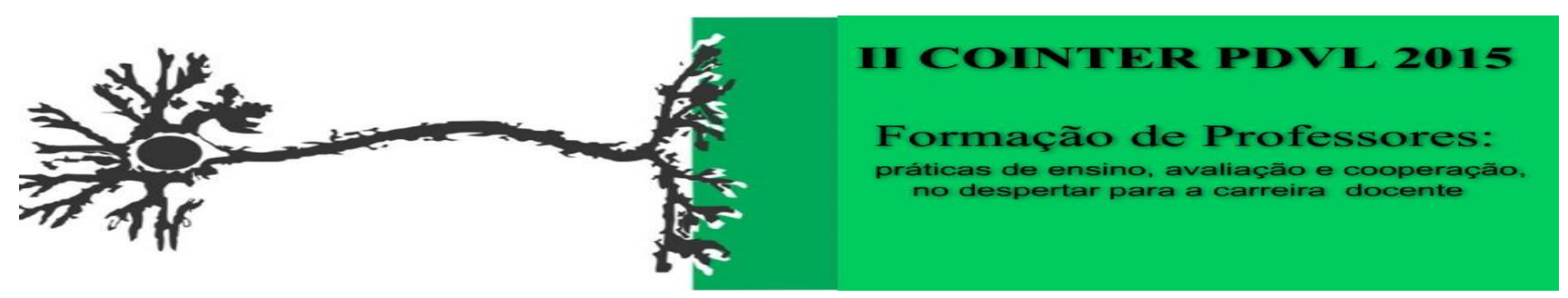

\title{
O PDVL COMO FERRAMENTA DE DESCOBERTA DE VOCAÇÕES À PRÁTICA DOCENTE
}

Apresentação: Relato de Experiência

CHAVES, Daniel de Assis ${ }^{1}$; ALEXANDRE, Glauris Ferreira ${ }^{2}$; CUSTÓDIO, Lucas Caetano de Oliveira ${ }^{3}$; NETO, Agamenon Barbosa da Silva ${ }^{4}$

\section{Introdução}

Com a proposta de despertar o interesse do alunado, especificamente do Ensino Médio, para licenciaturas, o Programa Despertando Vocações para as Licenciaturas (PDVL) realizou junto à comunidade estudantil da Escola Estadual de Ensino Fundamental e Médio José Baptista de Melo uma palestra que teve como foco a divulgação do referido programa e, ao mesmo tempo, estimular este público alvo a participarem das ações do PDVL - Química do IFPB/Campus João Pessoa, o qual objetiva o despertar para Licenciatura em Química a partir das atividades propostas.

\section{Relato de Experiência}

Com o intuito de propor uma nova visão em relação aos cursos de licenciatura e a formação de professores, o PDVL visa atenuar a problemática de insuficiência de docentes na educação básica e desinteresse por tal carreira. A falta de atratividade da profissão evidenciada pela ausência de recursos, principalmente, materiais e financeiros, contribui diretamente para uma visão errônea da carreira de professor. Essa realidade é percebida desde muito cedo pelos estudantes, onde os mesmos presenciam todas as dificuldades e desafios impostos à carreira do docente, fazendo com que essa realidade seja colocada de forma negativa na escolha profissional. Como explica Fanfani (2007, p. 335-354), há uma distância entre a imagem ideal do professor e a realidade da sua prática.

Como explica Tartuce, 2010:

\footnotetext{
“A diminuição da procura, por parte dos jovens, da profissão de professor tem-se tornado objeto de preocupação nos últimos anos. A falta de docentes bem formados e a escassez de profissionais para algumas áreas disciplinares dos últimos anos do ensino fundamental e
}

\footnotetext{
${ }^{1}$ Licenciatura em Química, Instituto Federal de Educação, Ciência e Tecnologia da Paraíba, danyel.pb@gmail.com

${ }^{2}$ Licenciatura em Química, Instituto Federal de Educação, Ciência e Tecnologia da Paraíba, glaurisferreira@hotmail.com

${ }^{3}$ Licenciatura em Química, Instituto Federal de Educação, Ciência e Tecnologia da Paraíba, lucascaetano95@hotmail.com

${ }^{4}$ Licenciatura em Química, Instituto Federal de Educação, Ciência e Tecnologia da Paraíba, netinhofera_94@hotmail.com
} 
ensino médio é discutida tanto em artigos acadêmicos como na mídia. Ao mesmo tempo, divulga-se não só a tendência de queda na demanda pelas licenciaturas e no número de formandos, mas também a mudança de perfil do público que busca a docência." (TARTUCE, 2010, p. 471)

Foram realizadas ações na Escola José Baptista de Melo (JBM), onde primeiramente foi apresentado um vídeo, criado pelo próprio PDVL - Química, para os alunos presentes, no qual foram mostradas de forma objetiva as propostas e futuras ações do projeto para que os mesmo se familiarizem com o referido programa. E logo após, foi ministrada uma palestra onde foram abordadas informações do processo de participação do aluno, esclarecimento de dúvidas e maneiras de estreitar relações entre os integrantes do projeto e o alunado.

Essas ações foram aplicadas nas turmas do $1^{\circ}$ e $2^{\circ}$ Ano do Ensino Médio da escola JBM, em um universo de 47 alunos presentes que puderam conhecer as propostas do programa e bem como esclarecer suas dúvidas e despertar o interesse de participação. Foi verificado que 35 alunos, representando cerca de $75 \%$ do total, demonstraram interesse em ingressar nas futuras atividades e alegaram entusiasmo com as propostas do PDVL. Dessa forma, contribuímos de forma significativa para destacar o papel do professor no contexto social e agente formador e propagador de conhecimento e mostrou uma nova perspectiva relacionada à profissão aos discentes.

Para mudar essa concepção em relação às licenciaturas e convocar esses futuros profissionais para desempenhar o papel de educador foi mostrada a importância da carreira do professor na propagação do saber e formação de cidadãos conscientes de seu papel na sociedade.

\section{Considerações}

É importante salientar que o interesse observado nesses estudantes é um grande estímulo para contribuir no processo de formação de futuros educadores, diminuindo o distanciamento dos alunos com a realidade vivenciada nos cursos de licenciatura e buscando propostas de melhorar a situação profissional do professor. Para tanto foi estabelecida uma relação mútua entre os participantes do PDVL e os alunados da referida escola.

\section{Referências}

FANFANI, E. T. Consideraciones sociológicas sobre profesionalización docente. Educação \& Sociedade, Campinas, vol. 28, n. 99, p. 335-354, maio/ago, 2007.

TARTUCE, G. L. B. P., NUNES, M. M. R., ALMEIDA, P. C. A. DE, alunos do ensino médio e atratividade da carreira docente no Brasil. Cadernos de Pesquisa, v.40, n.140, p. 471, maio/ago, 2010. 